Kajian Ilmiah Mata Kuliah Umum

Volume 15 Nomor 1, September 2015

Penerbit
Pelindung dan Penasehat
Penanggung Jawab
Pemimpin Umum
Penyunting Ahli
Pemimpin Redaksi
Sekretaris Redaksi
Anggota Redaksi

Sekretariat
: Pusat MKU Universitas Negeri Yogyakarta

: Wakil Rektor I UNY

: Wawan S. Suherman

: Sunarso

: Marzuki

: Rukiyati

: Vita Fitria

: Sri Agustin Sutrisnowati, Amir Syamsudin, Syukri Fathudin Achmad Widdodo,

Benni Setiawan

: Ari Saraswati

Alamat Redaksi/Tata Usaha:
Pusat MKU UNY, Gedung LPPMP Lt.3 Sayap Timur
Kampus Karangmalang Yogyakarta
Email: mku@uny.ac.id, mku.uny@gmail.com, ruki1961@yahoo.com

HUMANIKA Kajian Ilmiah Mata Kuliah Umum menerima kiriman tulisan/artikel yang terkait dengan Mata Kuliah Umum (MKU), yang meliputi Pendidikan Agama, Pendidikan Pancasila, Pendidikan Kewarganegaraan, Ilmu Sosial Dasar, Ilmu Budaya Dasar, Ilmu Alamiah Dasar, dan Pendidikan Kependudukan dan Lingkungan Hidup, dengan ketentuan sebagai berikut:

1. Naskah dapat berupa hasil penelitian atau artikel ilmiah bebas dan belum pernah diterbitkan.

2. Naskah diketik dengan spasi satu setengah (1,5 spasi) dengan jumlah halaman 1015 halaman kuarto, diketik dengan MS Word ukuran font 12 Times New Roman.

3. Naskah memuat komponen: judul ( $<10 \mathrm{kata})$, nama penulis, alamat email, abstrak (100-150 kata), isi karangan (yang memuat pendahuluan, pembahasan, kesimpulan) dan daftar pustaka.

4. Naskah dikirim dalam bentuk print out dan soft copy.

5. Daftar pustaka ditulis secara alfabetis seperti berikut:

- Hidayat, Komaruddin. 2004. Menafsir Kehendak Tuhan. Jakarta: Serambi.

- Bagir, Haidar. 2012. "Syiah dan Kerukunan Umat". Republika. 20 Januari. 


\section{DAFTAR ISI}

Redaksi Humanika ........................................................................... i

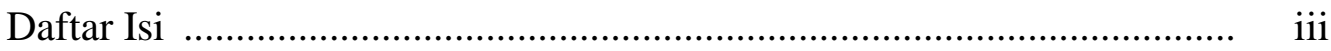

Pengantar Redaksi ...........................................................................

Islam Rahmah dan Wasathiyah

(Paradigma Keberislaman Inklusif, Toleran dan Damai)

Abd. Malik Usman........................................................................... 1-12

The Dialectics of Javanese and Islamic Cultures:

an Introduction to Kuntowijoyo's Thought

Pradana Boy ZTF

Persepsi Masyarakat Kotagede Terhadap Pengunaan Media Komunikasi oleh Organisasi Forum Joglo untuk Peletarian Budaya di Kotagede

Yogyakarta

Choirul Fajri

Implikasi Budaya Organisasi Terhadap Pola Perilaku Komunikasi

Kelompok Tani Sumber Rejeki

Mariana Ulfah dan Siti Chotijah

Etika Sosial dalam Kerukunan Umat Beragama

(Studi Kasus di Desa Kotesan Kecamatan Prambanan Kabupaten Klaten

Jawa Tengah)

Andy Dermawan dan Zunly Nadia

Model Komunikasi "Wom" Sebagai Strategi Pemasaran Efektif

Dani Fadillah

Mencari Model Pendidikan Karakter

Suparlan 


\title{
IMPLIKASI BUDAYA ORGANISASI TERHADAP POLA PERILAKU KOMUNIKASI KELOMPOK TANI SUMBER REJEKI
}

\author{
Mariana Ulfah dan Siti Chotijah \\ mj.mariajova@gmail.com \\ Universitas Ahmad Dahlan Yogyakarta
}

\begin{abstract}
Abstrak
Komunikasi dalam organisasi merupakan aspek yang penting guna menunjang kelangsungan orgnanisasi. Fungsi komunikasi sangat beragam sebagai upaya integrasi, persuasi serta informasi. Kelompok tani adalah salah satu organisasi kemasyarakatan yang penting untuk menopang perekonomian masyarakat pertanian. Setiap organisasi memiliki struktur dan berkomunikasi secara internal dan eksternal. Etnografi komunikasi merupakan metode yang alami untuk memotret fenomena komunikasi. Hal ini diperlukan untuk memberikan gambaran yang sealamiah mungkin serta memberikan penggambaran yang komprehensif terkait fenomena sosial. Komunikasi internal bersifat informal, sedangkan komunikasi eksternal lebih dinamis. Komunikasi dilakukan melalui komunikasi verbal dan nonverbal. Komunikasi verbal menunjukkan penggunaan tingkatan bahasa yang berbeda yang terintegrasi dengan nilai dan norma kelompok serta nilai sosial. Komunikasi nonverbal memiliki fungsi untuk mendukung atau menggantikan komunikasi verbal. Komunikasi baik verbal maupun nonverbal merupakan cerminan perilaku yang didasarkan pada konteks kultur dan kontekstual serta sistem pengetahuan yang melatarbelakangi anggota kelompok. Birokrasi membuat alur informasi serta pembagian hak serta kewenangan termasuk dalam komunikasi
\end{abstract}

Kata kunci: pola perilaku, komunikasi, budaya, organisasi, kelompok tani

\section{PENDAHULUAN}

Komunikasi dalam sebuah organisasi dapat dikatakan sebagai jantung dari organisasi. Hal ini memberikan gambaran bahwa komunikasi memiliki peran yang sangat signifikan terhadap dinamika organisasi dan upaya pencapaian tujuan. Setiap anggota kelompok akan selalu berkomunikasi dengan anggota lainnya untuk mencapai tujuan yang diinginkan. Komunikasi tidak hanya bersifat internal namun juga akan berlangsung dengan pihak diluar kelompok.

Kelompok tani Sumber Rejeki sebagai salah satu organisasi yang bergerak dalam bidang pertanian memegang peran penting di daerahnya dalam bidang keorganisasian, ekonomi maupun sosial. Sebagai kelompok tani yang dinilai kredibel, kelompok ini menjadi sumber belajar dan panutan bagi kelompok lainnya (Data Bank Indonesia Yogyakarta, 2011). Kelompok ini juga merupakan kelompok tani binaan Dinas Pertanian D.I Yogyakarta terutama dalam menyongsong program Global Gap.

Setiap kelompok seperti halnya kelompok tani Sumber Rejeki memiliki budaya organisasi yang berbeda dengan kelompok yang lain. Keberadaan budaya organisasi melalui berbagai perangkat aturan seperti AD ART, tata tertib, jabatan struktural (birokrasi) dalam kelompok dan kondisi geografis 
maupun demografis akan memberikan dampak yang signifikan terhadap pola perilaku komunikasi anggota kelompok. Sebagai salah satu kelompok tani binaan baik dari organisasi pemerintah yang bersifat nasional maupun daerah serta lembaga-lembaga non pemerintah, kelompok ini patut dan layak untuk diteliti. Secara tidak langsung kelompok ini mendapatkan pengaruh dari luar kelompok dalam hal pelatihan maupun penguatan kapasitas keorganiasian. Peneliti ingin mengetahui pengaruh tersebut terhadap pola perilaku komunikasi anggota kelompok baik dalam komunikasi internal maupun eksternal.

Pola perilaku komunikasi anggota menjadi penting terkait keberhasilan program-program yang dilaksanakan. Data dari Dinas Pertanian menyebutkan bahwa keberadaan kelompok tani dilihat secara perkembangannya cukup pesat, namun tidak lebih dari 50\% yang bertahan tanpa pendampingan. Salah satu faktor ketidakmampuan kelompok berjalan tanpa pendampingan adalah kemampuan berorganisasi dan berkomunikasi antar anggotanya. Peneliti menganggap ini menarik untuk diteliti mengingat kelompok tani menjadi bagian yang penting dalam roda perekonomian masyarakat yang berbasis pada pertanian. Bagaimana komunikasi organisasi dilakukan baik verbal dan nonverbal dalam alur komunikasi secara vertikal dan horizontal merupakan permasalahan yang layak diteliti.

Komunikasi organisasi adalah suatu bidang studi, penelitian dan terapan yang tidak menitikberatkan pada proses secara umum, tetapi pada tingkah laku (perilaku) individu dalam kelompok kecil. Komunikasi organisasi adalah pengiriman dan penerimaan pesan organisasi dalam kelompok formal maupun informal dalam sebuah organisasi (Wiryanto, 2005). Komunikasi formal dalam organisasi adalah komunikasi yang sifatnya disetujui dan berorientasi pada kepentingan organisasi. Isi komunikasi formal diantaranya adalah cara kerja dalam organisasi, produktifitas dan pekerjaan yang harus dilakukan dalam organisasi. Komunikasi informal adalah komunikasi yang disetujui secara sosial, orientasinya bukan pada kepeningan organisasi namun pada kepentingan personal anggota sebagai bagian dari kelompok.

Korelasi antara ilmu komunikasi dengan organisasi terletak pada manusia-manusia yang ada dalam organisasi dalam mencapai tujuannya. Ilmu komunikasi mempertanyakan bagaimana komunikasi yang berlangsung dalam organisasi, yang melibatkan hubungan antar anggotanya. Hal ini menyangkut metode komunikasi yang dilakukan, media apa yang digunakan serta faktor-faktor yang mempengaruhi seperti hambatan komunikasi. Komunikasi dalam organisasi memiliki berbagai fungsi diantaranya fungsi informatif, fungsi regulatif, fungsi integratif dan fungsi persuasif.

Sebagai bentuk sosialisasi individu, kelompok akan banyak memberikan pengaruh serta warna dalam perilaku anggotanya. Berikut ini adalah tiga pengaruh kelompok terhadap perilaku komunikasi anggotanya (Rakhmat, 2005: 149): 


\section{Konformitas}

Konformitas adalah perubahan perilaku atau kepercayaan menuju norma kelompok sebagai akibat tekanan kelompok yang nyata atau dibayangkan. Bila sejumlah orang dalam kelompok mengatakan atau melakukan sesuatu ada kecenderungan para anggota lainnya untuk mengatakan dan melakukan hal yang sama dengan anggota lainnya.

\section{Fasilitas sosial}

Fasilitasi artinya mudah menunjukkan kelancaran atau peningkatan kualitas kerja karena adanya kelompok. Kelompok mempengaruhi pekerja sehingga menjadi lebih mudah. Robert Zajnoz (dalam Rakhmat, 2005: 153) menjelaskan bahwa kehadiran orang lain dianggap menimbulkan efek pembangkit energi pada perilaku individu.

\section{Polarisasi}

Polarisasi adalah kecenderungan keposisi yang ekstrim. Bila sebelum diskusi kelompok para anggota mempunyai sikap agak mendukung tindakan tertentu, setelah diskusi mereka akan lebih kuat lagi mendukung tindakan tersebut. Budaya organisasi adalah keyakinan dan nilai bersama yang memberikan makna bagi anggota sebuah institusi dan menjadikan keyakinan dan nilai tersebut sebagai aturan atau pedoman berperilaku di dalam organisasi (Sobirin, 2007: 131). Budaya organisasi melahirkan pola perilaku yang ditunjukkan oleh sekelompok orang sebagai akibat dari internalisasi keyakinan dan tata nilai yang telah diperoleh pada waktu- waktu sebelumnya (accomodationist school).
Budaya organisasi memiliki 2 (dua) elemen yaitu elemen idealistik dan behavioral. Elemen idealistik menjadi ideologi organisasi, tidak mudah berubah meskipun organisasi selalu berubah dan beradaptasi dengan lingkungannya, bersifat terselubung, dan hanya orang- orang tertentu saja yang tahu mengapa organisasi itu mereka didirikan. Hofstede menyatakan elemen ini sebagai nilainilai organisasi. Elemen behavioral merupakan elemen yang muncul ke permukaan dalam bentuk perilaku sehari-hari para anggotanya dan bentuk bentuk lain seperti desain dan arsitektur organisasi.

Organisasi memiliki lapisan-lapisan layaknya sebuah bawang (Rousseau dalam Sobirin, 2007). Lapisan ini menunjukkan elemen-elemen yang ada dalam budaya organisasi. Elemen ini berkaitan satu sama lainnya sebagaimana elemen idealistik dengan elemen behavioral. Elemen yang ada dalam lapisan ini dari lapisan dalam keluar sebagai berikut:

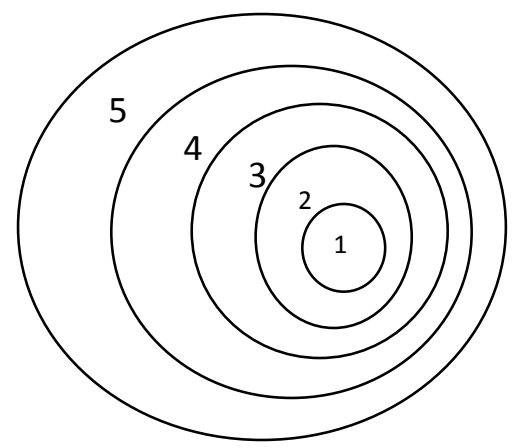

Gambar 2.1

Lapisan Elemen Budaya Organisasi Sumber : Rousseau dalam Sobirin (2007: 157) Keterangan Gambar:
1. Asumsi Dasar
2. Nilai
3. Norma
4. Perilaku
5. Artefak 
Asumsi dasar merupakan inti budaya organisasi. Budaya sebuah organisasi dalam banyak hal sangat dipengaruhi oleh asumsi yang berlaku dalam organisasi tersebut. Nilai-nilai organisasi adalah keyakinan yang dipegang teguh oleh seseorang atau sekelompok orang mengenai tindakan dan tujuan yang "seharusnya" dijadikan landasan atau identitas organisasi dalam menjalankan aktivitas, menetapkan tujuan atau memilih tindakan yang patut dijalankan dari alternatif pilihan yang ada. Artefak adalah elemen budaya yang kasat mata yang mudah diobservasi baik oleh orang dari dalam atau luar kelompok. Artefak merupakan perwujudan dari asumsi dasar serta nilai yang dalam penelitian ini wujud dari artefak adalah perilaku komunikasi.

Pada hakikatnya teori Weber (dalam Soekanto, 1969) memberikan implikasi pada komunikasi organisasi yaitu menunjukkan suatu fenomena yang disebut komunikasi jabatan (positional communication). Birokrasi sebagai sebuah sistem berarti sebagai sistem kerja yang berlandaskan kepada suatu jaringan tata hubungan kerjasama sesuai dengan tata aturan dan prosedur yang ditentukan. Birokrasi memiliki beberapa ciri diantaranya adalah:

1. Suatu organisasi terdiri dari hubungan-hubungan yang ditetapkan antara jabatan- jabatan

2. Tujuan atau rencana organisasi terbagi atas tugas-tugas yang disalurkan dalam berbagai jabatan sebagai kewajiban resmi

3. Kewenangan untuk melaksanakan kewajiban diberikan kepada jabatan

4. Garis kewenangan dan jabatan diatur menurut suatu tatanan hirarki
5. Sistem aturan dan regulasi yang umum tetapi tegas yang ditetapkan secara formal mengatur tindakantindakan dan fungsi jabatan dalam organisasi

Birokrasi dalam sebuah organisasi menunjukkan bagaimana struktur yang ada dalam organisasi tersebut. Struktur bagi Dalton (dalam Ndraha, 2005) dimaksudkan sebagai "patern a network of relationship between the various position and the position holders. Dalam penelitian ini hubungan struktur akan memberikan pengaruh terhadap pola dan relasi komunikasi yang terjadi antar anggota kelompok.

\section{POLA KOMUNIKASI}

Melihat perilaku komunikasi tidak terlepas dari lingkup sosial budaya, aspek kontekstual serta personal dari individu yang terlibat dalam proses komunikasi. Peneliti memberikan gambaran bahwa perilaku komunikasi melibatkan aspek-aspek makro (budaya) hingga pada tataran mikro (individual). Dalam ranah makro, keberadaan budaya serta lingkungan dimana individu tersebut tumbuh dan belajar akan memberikan dampak yang signifikan terhadap proses komunikasi yang berlangsung. Pada tataran interpersonal adalah menyangkut bagaimana individu meyakini nilai-nilai budaya tersebut dan mengaplikasikan dalam berbagai tindakan komunikasi. Dalam memahami perilaku, hal-hal yang diperhatikan dalam penelitian ini adalah faktor budaya, pengaruh kelompok serta bagaimana bentukbentuk perilaku tersebut.

Pola komunikasi dalam kelompok dapat dibedakan menjadi 2 macam yaitu 
perilaku komunikasi vertikal dan horizontal. Komunikasi vertikal dipahami sebagai komunikasi yang dilakukan antara satu bagian kelompok dengan bagian lain yang memiliki perbedaan strata. Sedangkan komunikasi horizontal terjadi antar anggota kelompok yang memiliki kedudukan yang sama. Hal-hal yang dapat mendorong terjadinya komunikasi vertikal maupun horizontal adalah birokrasi maupun strata sosial yang sesuai dengan nilai dan budaya yang diyakini oleh anggota kelompok.

Pola komunikasi anggota kelompok akan memperlihatkan arus informasi apakah bersifat top-down ataukah sebaliknya. Pola lain seperti one center person akan terlihat dalam analisis yang dipaparkan berdasarkan observasi yang dilakukan.Perilaku komunikasi sebagai cara bagaimana individu berkomunikasi yang meliputi komunikasi verbal maupun nonverbal (Devito, 1986). Cara berkomunikasi dapat diartikan sebagai cara berbicara, pemilihan bahasa, penggunaan isyarat, gestural, facial maupun postural dalam berkomunikasi. Komunikasi ini merupakan komunikasi langsung yang terjadi antara dua orang atau lebih yang terjadi secara langsung (face to face) atau sering disebut sebagai komunikasi interpersonal (Devito,1986: 119) .

Kedekatan komunikasi kelompok dengan komunikasi interpersonal adalah melibatkan dua orang atau lebih yang secara berdekatan menyampaikan pesan baik verbal maupun nonverbal. Komunikasi kelompok menempatkan individu dalam suasana yang lebih terstruktur, Individu melihat dirinya sebagai kelompok serta mempunyai kesadaran tinggi tentang sasaran bersama. Komunikasi dalam kelompok dilakukan secara sengaja, para peserta biasanya lebih sadar akan peran serta tanggung Jawabnya. Dean Barnlund (dalam Littlejohn, 1983: 161-162) memberikan definisi komunikasi interpersonal sebagai" the study interpersonal communication then, is concerned with the investigation of relativity informal situation in wich persons in face to face encounters sustain focused interaction through the reciprocal exchange of verbal and nonverbal cues". Definisi ini mengandung 5 (lima) kriteria tentang komunikasi interpersonal yaitu:

1. Terdapat dua orang atau lebih yang berdekatan secara fisik dan saling menyadari kehadiran satu sama lain.

2. Komunikasi interpersonal melibatkan kesalingtergantungan (communicative interdependence) yaitu satu perilaku komunikasi adalah konsekuensi langsung dari perilaku orang lainnya.

3. Komunikasi interpersonal mengakibatkan pertukaran pesan.

4. Pesan dalam komunikasi interpersonal dikode dalam berbagai simbol baik verbal maupun nonverbal.

5. Komunikasi interpersonal relatif tidak terstruktur, terjadi secara spontan, informal dan fleksibel.

\section{Komunikasi verbal dan nonverbal}

Komunikasi verbal adalah komunikasi bahasa yang dibayangkan sebagai kode atau sistem simbol yang digunakan untuk membentuk pesan-pesan verbal (Devito, 1997: 119). Pesan-pesan verbal merupakan rangkaian kata-kata yang 
dapat menjelaskan sesuatu dalam bentuk bahasa. Hocked (dalam Devito, 1997: 156) mengungkapkan bahwa bahasa dapat didefinisikan sebagai sistem produktif yang dapat dialihkan dan terdiri dari simbol-simbol yang cepat lenyap (rapidly fading) bermakna bebas (arbitary) serta dipancarkan secara kultural (Devito, 1997: 119).

Kelompok Tani Sumber Rejeki adalah kelompok yang tidak dapat dilepaskan dengan budaya Jawa sebagai suatu sistem dimana kelompok tersebut hidup dan berkembang. Budaya Jawa memiliki bahasa khusus yaitu bahasa Jawa. Dalam Bahasa Jawa terdapat berbagai tingkatan bahasa yang digunakan dalam percakapan. Penggunaan bahasa ini dipengaruhi oleh ruang, situasi, waktu serta siapakah lawan bicara kita. Dalam budaya Jawa perilaku komunikasi verbal melalui bahasa verbal akan menggambarkan sistem budaya yang ada. Sebagai contoh adalah penggunaan Bahasa Jawa "kromo hinggil" serta bahasa "Jawa ngoko". Penggunaan jenis bahasa ini mampu membedakan perilaku bagi individu. Penggunaan bahasa ini memiliki makna- makna khusus dan memiliki tujuan yang spesifik seperti rasa penghargaan dan penghormatan.

Bahasa nonverbal digunakan sebagai penegas dari bahasa verbal dalam proses komunikasi. Komunikasi nonverbal ini tercermin melalui gerak tubuh, mimik muka, ekspresi maupun komunikasi tubuh lainnya. Bahasa nonverbal disamping bersifat menegaskan komunikasi verbal juga mampu berkedudukan sebagai pengganti bahasa verbal. Bahasa nonverbal dalam perilaku komunikasi dinilai sangat komunikatif, artinya bahwa melalui bahasa nonverbal ini terdapat sesuatu yang dikomunikasikan. Komunikasi nonverbal terjadi dalam suatu konteks yang membantu menentukan makna dalam proses komunikasi (Devito,1997: 193). Dalam budaya Jawa komunikasi nonverbal merupakan jenis komunikasi yang lazim dilakukan dalam interaksi komunikasi. Setiap komunikasi nonverbal seperti gerakan tubuh, mimik muka maupun ekspresi memiliki makna yang berkaitan dengan bagaimana perilaku komunikasi yang dilakukan.

Peneliti akan melihat bagaimana perilaku komunikasi anggota KT Sumber Rejeki ini dengan teori-teori yang mampu Peneliti menggunakan symbolic interactionism theory dan communication accomodation theory. Kedua teori ini akan memberikan analisis terhadap perilaku komunikasi interpersonal anggota kelompok.

Symbolic interaction theory memberikan tema besar yaitu the importance of meaning for human behaviour, the importance of the self concept dan the relationship between the individual and society (Mead, 2010: 79). Tema pertama memberikan pemahaman bahwa dalam proses komunikasi, individu mengkonstruksi makna. Makna ini lahir atas interaksi yang terjadi antar individu dalam proses komunikasi. Makna lahir sebagai sebuah proses interpretatif selama proses interaksi berlangsung. Setiap perilaku individu termasuk perilaku komunikasi memiliki makna (Herbert Blumer dalam Turner, 2010: 80). Symbolic interaction theory juga memberikan pemahaman bagaimana 
individu mengembangkan konsep diri. Self concept dipahami sebagai " $a$ relatively stable set of perceptions people hold about themself'. Konsep diri ini akan berkembang selama individu berinteraksi dengan individu lainnya. Konsep diri ini akan melahirkan motif untuk berperilaku. Dalam penelitian ini individu dalam kelompok mendapatkan pengaruh dari keluarga, teman, relasi, maupun para pemateri ketika diadakan pelatihan. Individu- individu inilah yang membentuk self concept terhadap perempuan anggota Kelompok.

Symbolic interaction theory ini setidaknya memberikan 7 (tujuh) asumsi bahwa. Humans act towars others on the basis of the meaning those others have for them, Meaning is created in interaction bettween people, Meaning is modified through an interpretative process, Individuals develop self concept throught interaction with others, Self concepts provide and important motive for behaviour, People and groups are influenced by cultural and social prosses dan Social structure is worked out through social interaction (Mead dalam Thurner, 2010: 85). Mead juga menambahkan dalam symbolic interaction theory terdapat 3 konsep pokok yaitu mind, language dan significant symbols. Mind dipahami sebagai kemampuan individu untuk menggunakan simbol berdasar artinya secara umum, language dipahami sebagai pembagian simbol secara verbal dan nonverbal. Significant symbol merujuk pada pemahaman bahwa simbol memiliki arti yang disepakati oleh orang banyak.

\section{Communication accomodation} theory dikemukakan oleh Howard Giles dan koleganya, teori ini berkaitan dengan penyesuaian interpersonal dalam interaksi komunikasi. Hal ini didasarkan pada observasi bahwa komunikator sering kelihatan menirukan perilaku satu sama lain. (West dan Turner, 2007: 217) Akomodasi didefinisikan sebagai kemampuan menyesuaikan, memodifikasi atau mengatur perilaku seseorang dalam responnya terhadap orang lain. Akomodasi biasanya dilakukan secara tidak sadar. Kita cenderung memiliki naskah kognitif internal yang kita gunakan ketika kita berbicara dengan orang lain. Teori akomodasi menyatakan bahwa dalam percakapan orang memiliki pilihan. Mereka mungkin menciptakan komunitas percakapan yang melibatkan penggunaan bahasa atau sistem nonverbal yang sama, mereka mungkin akan membedakan diri mereka dari orang lain, dan mereka akan berusaha terlalu keras untuk beradaptasi. Pilihanpilihan ini akan diberi label konvergensi, divergensi, dan akomodasi berlebihan. Teori akomodasi komunikasi memberikan asumsi bahwa persamaan dan perbedaan selalu ada dalam setiap percakapan. Evaluasi dari percakapan dapat dilakukan dengan melihat percakapan serta perilaku yang dilakukan. Bahasa dan perilaku dalam teori ini menunjukkan status sosial dan group belonging.

\section{METODE PENELITIAN}

Penelitian ini adalah penelitian kualitatif dengan metode etnografi komunikasi. Pendekatan ini merupakan 
gabungan dari etnografi dan komunikasi dengan spesifikasi melihat cara berkomunikasi pada sebuah komunitas. Nelson menyatakan bahwa penelitian kualitatif merupakan bidang antar disiplin, lintas disiplin maupun kontra disiplin (Denzin, 1997: 5).

Peneliti membedakan perilaku komunikasi menjadi dua jenis yaitu komunikasi internal dan komunikasi eksternal. Komunikasi internal merupakan komunikasi yang terjadi antar anggota Kelompok. Komunikasi eksternal merupakan komunikasi yang berlangsung antara anggota kelompok dengan individu yang bukan merupakan anggota kelompok.

Penelitian ini membahas komunikasi yang terjadi dalam kelompok tani Sumber Rejeki terkait bagaimana komunikasi yang terjadi baik formal maupun informal. Sesuai konsep penelitian, komunikasi akan dibedakan dalam komunikasi internal serta komunikasi eksternal. Komunikasi internal melibatkan internal anggota sedangkan komunikasi eksternal melibatkan pihak dari luar kelompok. Dalam birokrasi akan terlihat adanya komunikasi yang bersifat horizontal serta komunikasi yang sifatnya vertical.

Kerangka konseptual ini akan memberikan gambaran tentang kajian yang akan diteliti. Unit kajian dalam penelitian ini adalah definisi operasional yang merupakan fokus kajian peneliti dalam memotret perilaku anggota kelompok.

Subjek penelitian adalah Kelompok Tani Sumber Rejeki yang merupakan salah satu kelompok yang berprestasi dan mendapatkan banyak perhatian dari lembaga pemerintah maupun non pemerintah. Hal ini diwujudkan dalam berbagai program pendampingan , pelatihan dan penguatan kapasitas yang berbasis mandiri. Kelompok ini beranggotakan sekitar 40 orang petani salak yang berlokasi di dusun Soka Tegal Merdikorejo Tempel Sleman Yogyakarta. Secara geografis wilayah ini berada pada lereng gunung Merapi dan berjarak sekitar $25 \mathrm{~km}$ dari pusat Kota Yogyakarta. Perjalanan dapat ditempuh dengan kendaraan sekitar 30 menit. Kelompok ini diprakarsai oleh sebagian anggota dengan tujuan memakmurkan ekonomi anggota yang berbasis pada pertanian salak pondoh. Kelompok ini memiliki tata tertib,AD/ART dan ketentuan lainnya yang telah disepakati dalam rapat anggota.

Kelompok Tani Sumber Rejeki menjadi objek penelitian karena memiliki karakteristik yang memadai. Karakteristik tersebut diantaranya telah teruji secara konsisten dalam kegiatan serta program yang berjalan. Anggota kelompok juga telah mendapatkan bekal yang cukup melalui pelatihan terpadu mapun pengiriman duta kelompok ke dalam forum seminar baik lokal maupun nasional.

Teknik pengumpulan data yang digunakan adalah observasi partisipatoris, wawancara mendalam, dan studi dokumen. Informan diperoleh dengan menggunakan metode snow ball yaitu penunjukan oleh informan sebelumnya dengan menambahkan beberapa pertimbangan dari peneliti. Peneliti melakukan wawancara mendalam kepada 9 informan secara maju bertahap. Beberapa pertanyaan 
diulang pada kesempatan yang berbeda untuk menguji validitas data.

Analisis data menggunakan model etnografi komunikasi. Etnografi komunikasi menjadi lebih luas karena tidak hanya melingkupi modus komunikasi lisan (speaking), tetapi juga melibatkan komunikasi tulis (writing) serta komunikasi isyarat (gesture), gerakan tubuh (postural), atau tanda (signing). Etnografi komunikasi memusatkan diri pada pola- pola interaksi diantara para anggota sebuah kelompok budaya tertentu maupun kelompok yang memiliki budaya berbeda. Etnografi dalam penelitian ini memiliki alur yang diadopsi dari langkah- langkah etnografi LeCompe dan Schensul.

\section{HASIL PENELITIAN DAN PEMBAHASAN}

Kelompok Tani Sumber Rejeki beranggotakan laki- laki dan seluruhnya adalah penduduk padukuhan Soka Tegal. Data demografi anggota terlihat pada tabel berikut.

Tabel 1. Usia Anggota KT Sumber Rejeki

\begin{tabular}{|l|c|}
\hline Usia & Jumlah \\
\hline $30-40$ tahun & 5 \\
\hline $40-50$ tahun & 21 \\
\hline 50 tahun keatas & 14 \\
\hline
\end{tabular}

Sumber: Data KT Sumber Rejeki 2013 (diolah)

Sedangkan tingkat pendidikan anggota KT Sumber Rejeki sebagai berikut.
Tabel 2. Tingkat Pendidikan Anggota KT

\begin{tabular}{|l|c|}
\hline Usia & Jumber Rejeki \\
\hline SD & 3 \\
\hline SMP & 12 \\
\hline SMA & 21 \\
\hline Sarjana (S1) & 3 \\
\hline Pascasarjana (S2) & 1 \\
\hline
\end{tabular}

Sumber: Data KT Sumber Rejeki 2013 (diolah)

\section{Komunikasi Internal Anggota KT Sumber Rejeki}

Bahasa yang digunakan adalah Bahasa Jawa kromo hinggil, alus, ngoko dan Bahasa Indonesia. Bahasa Jawa merupakan bahasa mayoritas anggota kelompok. Ragam bahasa ini memiliki aturan serta kesesuaian. Peneliti menemukan perbedaan penggunaan bahasa Jawa dalam percakapan seharihari baik dalam kegiatan formal maupun kegiatan informal.

Pada dasarnya bentuk komunikasi dalam komunikasi internal merupakan komunikasi informal baik verbal maupun nonverbal. Sebagai contoh ketika gotong royong, para anggota kelompok tani bicara soal ketersediaan bibit salak madu, sambil istirahat menikmati snack, minuman, merokok, dan dengan posisi santai duduk di pagar, atau berdiri, dengan sesekali bercanda. Bahkan peneliti melihat seorang anggota yang menunjuk wajah temannya, dimana hal ini dianggap tidak sopan kecuali ada kedekatan emosional. Rapat rutin adalah suasana paling serius dalam agenda kelompok. Namun demikian suasana kekeluargaan masih sangat terasa. Ini dilihat celetukan-celetukan 
dan tawa anggota kelompok. Cara duduk mereka pun santai, bersila sambil menikmati rokok atau hidangan. Bahasa yang digunakan merupakan kombinasi antara Bahasa Indonesia dan Bahasa Jawa halus bahkan ngoko. Komunikasi internal mayoritas menggunakan bahasa lisan. Bahasa tulisan hanya digunakan untuk undangan maupun selebaran terkait materi penyuluhan yang didapatkan perwakilan anggota saat pelatihan.

Secara umum perlakuan antar individu cenderung sama. Hanya beberapa anggota yang diperlakukan berbeda dalam berbicara. Mereka adalah para pejabat seperti Sekretaris Desa,Kaur Kesra Desa Merdikorejo dan Kepala Dusun. Contoh ketika Thr menanyakan tentang mesin diesel kepada Sekretaris Desa. Pak Thr bertanya dengan suara pelan dan menggunakan Bahasa Jawa kromo hinggil. Sebelum bicara pun didahului dengan permohonan maaf. 'Nyuwun pangappunten Pak Pur, diesel wonten pundhi njih ?' (Mohon maaf Pak Pur, Diselnya dimana ya?). Hal ini berbeda ketika bertanya pada Skm yang bukan pejabat pemerintah desa, 'Man diesel nangdi yo ' (Man dieselnya dimana ya). Penggunaan bahasa yang berbeda ini merupakan penghargaan sebagai masyarakat Jawa yang kolektif dan memegang teguh aturan serta norma di masyarakat.

Jabatan kemasyarakatan lebih dominan memberikan jarak dalam berkomunikasi dibanding faktor lain seperti umur dan ekonomi. Orang yang lebih tua namun tidak berjabatan kemasyarakatan tidak lebih dihormati dari anggota yang muda dengan jabatan penting. Sebagai contoh adalah Utm sebagai anggota paling tua tidak diperlakukan sebagaimana Why yang seusia anaknya, namun berjabatan penting di masyarakat.

Perilaku komunikasi anggota kelompok sangat akomodatif. Terdapat kesepahaman terkait permasalahan atau kepentingan kelompok. Tidak terdapat gejolak perbedaan ide maupun gagasan antar anggota. Terhadap anggota yang dihormati lebih akomodatif. Misalnya ketika Sekretaris Desa hendak mengambil cangkul, tiba-tiba anggota lain bergegas mengambilkan. Sebaliknya, Sdi yang juga akan mengambil cangkul hanya dikomentari dengan canda 'nah lek ndang macul lek' (Nah, segera mencangkul Lek). Mereka juga akan memperingatkan anggotanya yang dinilai acuh terhadap seorang yang dihormati.

\section{Komunikasi Eksternal Anggota KT Sumber Rejeki}

Komunikasi eksternal adalah komunikasi antara anggota KT Sumber Rejeki dengan individu dari luar kelompok seperti petugas dinas pertanian, tokoh masyarakat, serta masyarakat umum yang berkepentingan. Mayoritas perilaku yang ditunjukkan adalah perilaku yang overakomodatif. Komunikasi eksternal memiliki warna berbeda dengan komunikasi internal, karena terkesan dibuat-buat. Kelompok ini pernah beberapa kali mendapatkan kunjungan dari Dinas Pertanian Propinsi DIY. Peneliti menilai dari data-data yang dikumpulkan seperti foto kegiatan menunjukkan perilaku yang 
overakomodatif. Jika tamunya adalah orang Jawa maka komunikasi yang digunakan adalah Bahasa Jawa kromo hinggil meskipun usia tamu lebih muda.

Ketika berkomunikasi dengan pihak eksternal, anggota kelompok terkesan lebih berhati-hati, karena enggan dan kurang pede. Anggota lebih mempercayakan kepada pengurus yang didampingi pejabat pemerintah untuk berkomunikasi dengan pihak eksternal. Hal ini dianggap lebih sopan dan secara struktural telah mewakili seluruh anggota kelompok. Komunikasi eksternal memiliki banyak karakteristik yang jauh berbeda dengan komunikasi internal. Kesan formal ditunjukkan ketika ketua kelompok maupun perwakilan anggota sangat serius dalam berkomunikasi, saat penyambutan, setting lokasi serta kelengkapan administratif dan konsumsi yang diberikan.

Kelompok ini beberapa kali berkesempatan wawancara langsung dengan pegawai Dinas Pertanian guna kesiapan program yang akan dilaksanakan. Pengurus memegang kendali penuh untuk agenda semacam ini. Hal ini bertujuan agar informasi yang disampaikan terintegrasi dengan baik. Pengurus dinilai cakap dalam memberikan pemahaman terkait hal-hal yang menyangkut kelompok. Pengurus memberikan informasi sedemikian rupa, detail dan menyeluruh terkait apa yang ditanyakan oleh pewawancara. Keberhasilan komunikasi yang dilakukan menentukan apakah kelompok ini layak atau tidak untuk mendapatkan program dari pemerintah.

Peneliti menilai bahwa kelompok ini memiliki kemampuan berkomunikasi serta bernegosiasi cukup bagus. Hal ini tercermin dengan diloloskannya KT Sumber Rejeki sebagai salah satu percontohan kelompok tani mandiri dan diikut sertakan dalam program Global Gab yaitu pendampingan dan penguatan kapasitas kelompok pertanian guna menyongsong era global. Pada akhir tahun 2012 kelompok ini mendapatkan kunjungan dari Jerman dan Belanda. Peran Dinas pertanian sangat besar termasuk dalam mendampingi kelompok untuk berkomunikasi dengan pihak asing. Hambatan yang terasa adalah ketidakmampuan anggota untuk berbahasa asing. Anggota kelompok dalam event pelatihan cenderung diam dan mendengarkan (mute group)s. Informasi yang diberikan cenderung searah, minim diskusi dan suasana formal. Para anggota kelompok duduk rapi, tenang tanpa canda tawa dan konsentrasi pada materi yang diberikan Selain bahasa yang digunakan juga formal, gerak tubuh yang ditunjukkan sangat sopan. Tampak dari cara berjabat tangan, dimana anggota menggunakan 2 tangan dan membungkukkan badan hingga 30 derajat. Sebagai informasi kelompok ini telah mendapatkan pelatihan terpadu yang dilaksanakan di PKBM Ngudi Ngelmu dengan pembicara tim ahli penunjukan dari Dinas Pertanian Provinsi.

Komunikasi eksternal memberikan pemahaman bahwa ada jarak antara anggota dengan tamu (pemateri). Seperti halnya tempat duduk yang disediakan secara istimewa yaitu kursi khusus yang terpisah dari anggota pada umumnya. Pengurus ditugaskan untuk menjamu pemateri maupun tamu 
tamu lain dan mewakili kelompok. Komunikasi eksternal ini hanya dapat dilihat pada agenda khusus saja. Dalam 2 bulan waktu penelitian terdapat dua kegiatan yang melibatkan pihak eksternal. Namun sangat jelas perbedaan yang terlihat antara komunikasi internal dan eksternal. Materi yang menjadi bahan komunikasipun berbeda, jika dalam komunikasi internal jokes atau guyonan adalah biasa, namun dinilai tidak sopan dalam komunikasi eksternal. Berikut ini adalah perbedaan yang ditemukan dalam komunikasi internal dan eksternal sebagaimana tampak dalam tabel berikut.

Tabel 3. Temuan Perbedaan Karakteristik Komunikasi Internal dan Eksternal

\begin{tabular}{|l|l|l|}
\hline $\begin{array}{l}\text { Bahasa } \\
\text { verbal }\end{array}$ & $\begin{array}{l}\text { Bahasa Jawa } \\
\text { halus, bahasa } \\
\text { Jawa Ngoko }\end{array}$ & $\begin{array}{l}\text { Bahasa Jawa } \\
\text { Kromo Hinggil } \\
\text { dan Bahasa } \\
\text { Indonesia }\end{array}$ \\
\hline $\begin{array}{l}\text { Bahasa } \\
\text { Nonverbal }\end{array}$ & $\begin{array}{l}\text { Gesture santai, } \\
\text { ekspresif, } \\
\text { postur } \\
\text { fleksibel }\end{array}$ & $\begin{array}{l}\text { Kurang } \\
\text { ekspresif, } \\
\text { terkesan kaku } \\
\text { dan berjarak }\end{array}$ \\
\hline $\begin{array}{l}\text { Sifat } \\
\text { komunikasi }\end{array}$ & Informal & Formal \\
\hline Pelaku & $\begin{array}{l}\text { Antar anggota } \\
\text { kelompok }\end{array}$ & $\begin{array}{l}\text { Anggota } \\
\text { kelompok } \\
\text { dengan pihak } \\
\text { dari luar } \\
\text { kelompok }\end{array}$ \\
\hline $\begin{array}{l}\text { Power } \\
\text { distance }\end{array}$ & $\begin{array}{l}\text { Status social, } \\
\text { usia dan } \\
\text { jabatan dalam } \\
\text { kelompok }\end{array}$ & Jabatan, status \\
\hline $\begin{array}{l}\text { Bop Down, } \\
\text { Komunikasi } \\
\text { sesuai struktur } \\
\text { birokrasi }\end{array}$ & Dinamis \\
\hline
\end{tabular}

Analisis Implikasi Budaya Organisasi Dalam Perilaku Komunikasi

Budaya organisasi dalam penelitian ini juga tertuang dalam ADART kelompok, norma sosial serta berbagai nilai yang ada dalam kelompok. AD-ART KT Sumber Rejeki ini dibuat berdasarkan kesepakatan anggota dan dibimbing oleh petugas PPL Pertanian Kecamatan Tempel. Dari AD-ART diatas diketahui bahwa struktur kepengurusan pada KT Sumber Rejeki ini cukup unik yaitu dengan adanya jabatan rangkap baik ketua, sekretaris maupun bendahara. Dari observasi yang dilakukan diketahui bahwa aliran informasi dalam kelompok sesuai dengan pola struktur kepengurusan. Sebagai contoh adalah ketika terdapat sosialisasi pelatihan dari dinas pertanian propinsi, informasi masuk melalui ketua dan ketua memberikan informasi kepada seluruh anggota pada saat rapat pertemuan rutin.

Ketua dalam contoh diatas memiliki wewenang untuk memimpin kelompok, menyebarkan informasi kepada anggota dan menindaklanjuti adanya informasi tersebut. Struktur kepengurusan menentukan arus informasi yaitu dari pengurus kepada anggota. Anggota dalam hal mencari informasi akan menghubungi pengurus yaitu ketua atau sekretaris. Strutur ini memberikan gambaran bahwa kepengurusan dinilai cukup efektif dalam hal menunjang komunikasi anggota dalam hal pencarian informasi.

Dari wawancara mendalam ditemukan fakta bahwa status sosial kemasyarakatan mempengaruhi dalam penetapan kepengurusan kelompok. Sebagai contoh terkait pemilihan ketua kelompok. Ketua I dan ketua II adalah orang yang cukup terpandang dalam masyarakat. Ketua I Bapak Krjy dinilai cakap dalam hal administrasi dan 
kepemimpinan mengingat yang bersangkutan adalah pegawai Pemda. Bapak PS diangkat menjadi ketua dikarenakan senioritas secara umur dan kemampuannya dalam mengorganisikan masyarakat. Kepengurusan dipilih oleh anggota dalam rapat kelompok, namun namanama yang diajukan bersifat aklamasi yaitu usulan dari satu atau dua orang dan disetujui secara mutlak oleh anggota rapat.

Keunikan lain adalah adanya hak dari pengurus untuk melakukan penunjukan kepada pihak luar yang dinilai cakap dan kompeten untuk memberikan pendampingan terhadap kelompok. Hal ini membuka jalan adanya komunikasi eksternal yaitu atara anggota kelompok dengan pihak terkait yang dipercaya untuk melakukan pendampingan. Secara struktural individu yang ditunjuk bekerja dibawah mandat pengurus (ketua) namun dari hasil pengamatan diketahui bahwa individu dari luar kelompok yang disebut sebagai konsultan atau tim ahli ini mendapatkan penghargaan yang begitu istimewa.

Peneliti melihat perlakuan yang sangat istimewa, termasuk dalam hal berkomunikasi terhadap konsultan atau tim ahli ini. Sebagai contoh adalah cara berbicara para anggota dengan PPL Pertanian Kecamatan. Semua anggota memberikan penghormatan kepada PPL Kecamatan karena PPL dinilai memiliki power yang lebih dalam hal pengetahuan pertanian maupun positioning sebagai wakil dari Dinas Pertanian. Hal ini sesuai dengan hasil wawancara mendalam dengan Bapak Hynt yang menyatakan bahwa status
PPL sebagai pembimbing kelompok merupakan posisi yang wajib dihormati. Selain memberikan ilmu, jasa dan kemampuannya dalam memajukan kelompok patut diapresiasi.

Budaya Jawa sebagai norma yang berlaku dalam sosial kemasyarakatan KT Sumber Rejeki memberikan pemahaman bahwa 'tamu' atau orang luar yang datang kedalam kelompok wajib dihormati dan diperlakukan secara baik. Hal ini menyangkut penghormatan, norma serta pembentukan citra KT Sumber Rejeki sebagai kelompok tani yang mandiri, professional dan beretika.

Penghormatan ini dapat dilihat dengan gaya bicara yang menggunakan bahasa kromo hinggil. Meskipun petugas PPL secara umur lebih muda dibanding anggota kelompok, para anggota tidak segan segan untuk berbicara dengan bahasa kromo hinggil. Hal ini merupakan simbolisasi penghormatan mengingat kromo hinggil adalah bahasa tertinggi dalam bahasa Jawa. Bahasa kromo hinggil biasa digunakan untuk orang yang dihormati secara status sosial.

Anggota kelompok tidak sepenuhnya memahami AD ART kelompok. Dari wawancara yang dilakukan mereka mengetahui adanya AD ART kelompok, namun tidak hafal dan hanya poin poin tertentu yang diingat secara pasti seperti tugas dan wewenang pengurus serta mekanisme rapat. Informan memberikan gambaran bahwa harmonisasi kelompok lebih dipengaruhi budaya secara makro yaitu nilai- dan norma budaya sebagai orang Jawa. Sebagai contoh adalah adanya musyawarah mufakat, rasa empati antar 
anggota, sikap terbuka dan rasa kekeluargaan yang kuat. Hal ini terlihat sangat kuat dikarenakan sebelum terbentuknya kelompok, anggota adalah orang yang berasal dari satu pedukuhan, saling mengenal dengan baik dan telah tergabung dalam berbagai organisasi kemasyarakatan lainnya.

Standpoint theory menyatakan bahwa perilaku individu dalam kelompok kecil tidak dapat dilepaskan dari pengaruh sistem budaya dimana organisasi tersebut tumbuh dan berkembang. Peneliti menemukan adanya dua macam aturan yaitu aturan tertulis (AD ART) serta peraturan tidak tertulis yaitu norma- norma serta nilai sosial. Korelasi ini membuat perilaku anggota kelompok tidak dapat dipisahkan dari budaya Jawa sebagai budaya dominan.

Perilaku dalam konteks komunikasi merupakan gabungan antara sistem pengetahuan dengan sistem tindakan yang dilator belakangi faktor kultural serta faktor kontekstual. Perilaku memilih tingkatan bahasa sebagai salah satu temuan dalam penelitian ini adalah sebuah tindakan yang dimotori sistem pengetahuan tentang fungsi tingkatan bahasa dalam budaya Jawa. Faktor kontekstual berperan dalam memberikan dorongan atau motivasi dari tindakan. Motivasi anggota dalam berkomunikasi cukup beragam. Komunikasi dilakukan untuk berbagai tujuan baik secara pekerjaan atau sosial. Dalam hal pekerjaan komunikasi dilakukan untuk mencari informasi, memberikan penugasan, memberikan laporan serta membagi informasi. Sedangkan konteks sosial komunikasi berfungsi untuk menjaga hubungan. Masyarakat Jawa sebagai masyarakat kolektif memiliki budaya bertegur sapa ketika bertemu. Hal ini dilakukan atas dasar norma serta kebiasaan yang ada dalam masyarakat.

Peneliti dalam observasi mengamati ketika Bapak Skm bertemu dengan Bapak Dasri dan Bapak Pwt. Informasi yang didapat adalah Bapak Pwt merupakan salah satu perangkat desa dan cukup dihormati dikalangan masyarakat. Bapak Dasri adalah salah seorang petani biasa dan tidak memiliki jabatan dalam kelompok maupun struktur kemasyarakatan lainnya. Dari observasi ditemukan adanya perbedaan perilaku Bapak Skm dengan Bapak Dasri serta Bapak Pwt.

Bapak Skm ketika bertemu Bapak Pwt berusaha mendekat, tersenyum dan membungkukkan badan sambil menyapa dengan bahasa Jawa kromo hinggil ' badhe tindak pundi pak (mau kemana pak) sedangkan ketika bertemu Bapak Das, Pak Skm ini berucap `nangdi kang` (mau kemana kang) sambil tetap melaju diatas sepeda motornya. Perilaku diatas mencermintan penghargaan dan penghormatan yang berbeda dilihat dari pemilihan bahasa serta komunikasi nonverbal yaitu gestur, postur dan jarak dalam komunkasi.

Budaya organisasi memiliki lapisan- lapisan layaknya sebuah bawang (Rousseau dalam Sobirin, 2007). Lapisan ini menunjukkan elemen yang ada dalam KT Sumber Rejeki. Sebagaimana kelompok lainnya, KT Sumnber Rejeki memiliki asumsi dasar, nilai, norma serta elemen idealistiknya sebagai organisasi. Dalam hal budaya organisasi peneliti menemukan sebuah 
akulturasi antara gaya organisasi modern dengan gaya organisasi tradisional. Gaya organisasi modern ini ditunjukkan dengan adanya struktur baku kelompok, tata tertib dan adanya kegiatan administratif kelembagaan. Gaya tradisional juga tidak dapat ditinggalkan seperti adanya rotasi tempat perkumpulan yaitu anjangsana rumah ke rumah anggota meskipun KT Sumber Rejei memiliki base camp yaitu di Gedung PKBM Ngudi Ngelmu.

Anggota kelompok memiliki asumsi dasar yaitu kesepahaman sebagai petani salak pondoh yang mengupayakan kemandirian ekonomi, peningkatan kesejahteraan melalui pertanian. Asumsi ini mempengaruhi perilaku anggota untuk mengutamakan kepentingan bersama daripada kepentingan pribadi. Dalam komunikasi kelompok kita mengenal adanya konformitas. Anggota kelompok akan mengikuti apa yang dilakukan kebanyakan anggota lainnya.

Dalam budaya organisasi nilai dan norma sebagai elemen penting dapat dilihat baik secara nyata maupun fenomena yang laten. Sebagai contoh adalah adanya pengaruh power distance baik dalam komunikasi internal maupun eksternal. Indikator power distance ini beragam. Indikator dalam komunikasi internal dapat dengan mudah dilihat seperti jabatan dalam kelompok, umur (senioritas) serta aspek ekonomi yang melatarbelakangi.

Peneliti melihat bahwa realita pelaksanaan aturan dan tata tertib kelompok sudah bagus. Hal ini dilihat dari keharmonisan kelompok serta tidak adanya konflik yang berarti dalam KT Sumber Rejeki. Dalam wawancara mendalam peneliti tidak menemukan adanya konflik besar, hanya beberapa keluhan terkait ketertiban anggota dalam pelaksanaan gotong royong. Jika kegiatan gotong royong dilakukan di hari libur hampir seluruh anggota mengikuti, namun bila ada kegiatan pada hari dan jam kerja secara otomatis tidak semua anggota dapat mengikuti kegiatan tersebut. Keluhan dari beberapa anggota adalah tidak adanya sanksi atau denda kepada yang absen. Peneliti menanyakan apakah yang bersangkutan sudah pernah menyampaikan keluhan tersebut pada saat rapat dan Jawaban dari anggota tersebut adalah 'wah, belum rodo pekewuh Mbak' (wah belum, agak tidak enak Mbak).

Budaya Jawa memiliki karakter yang tidak terlalu terbuka terutama dalam hal kritik (Esti Ismawati, 2005). Sikap yang ditunjukkan anggota tersebut dapat dikategorikan sebagai hambatan dalam komunikasi. Motivasi dari perilaku tersebut secara kultural bagus yaitu untuk menjaga harmonisasi hubungan personal, namun secara proses komunikasi hal ini kurang memberikan efek yang baik terhadap keberlangsungan komunikasi dalam kelompok. Persoalannya adalah ketika hal ini dapat diredam tidak menjadi masalah namun jika keberatan tersebut berkelanjutan dan mendorong turunnya produktifitas tentu saja hal ini akan menimbulkan masalah.

Kasus diatas memberikan gambaran bahwa komunikasi dalam kelompok tidak sepenuhnya berjalan lancar yang diakibatkan oleh faktor kultural maupun personal. Perasaan tidak enak, keengganan menegur atau 
menyampaikan pendapat dalam proses komunikasi kelompok dapat dikategorikan sebagai noise atau hambatan. Semakin kecil hambatan yang ada dalam proses komunikasi kelompok maka hubungan yang terjalin antar anggota dalam kelompok semakin baik, demikian sebaliknya jika hambatan ini pada suatu ketika dirasakan cukup berarti maka hal ini akan memunculkan adanya konflik. Peneliti dalam observasi tidak melihat hal ini sebagai pemicu konflik karena sebagian anggota yang aktif masih dapat 'nrimo'.

Hofstede menyatakan bahwa komunikasi melibatkan jarak kekuasaan antara kommunikator dan komunikasn. Dalam teory budaya hal ini disebut sebagai power distance. Peneliti menganalisa bahwa power distance dalam kelompok ini cukup beragam. Faktor usia dimana mayoritas anggota memiliki usia diatas 40 tahun, hal ini menunjukkan kematangan secara usia dengan dilihat melalui kematangan karakter sebagai orang Jawa. Usia tidak menjadi hal pokok dalam permasalahan jarak kekuasaan. Observasi menunjukkan bahwa tidak selalu orang yang muda lebih menghormati yang lebih tua.

Contoh kasus adalah Bapak Sdi yang usianya 55 tahun berlaku sangat hormat dengan Bapak Yun yang usianya 45 tahun. Fenomena ini terlihat sebagai sebuah anomali jika dikaitkan dengan norma dasar budaya Jawa dimana yang muda menghormati yang tua. Dalam wawancara yang dilakukan peneliti menemukan alasan kenapa Bapak Sdi berlaku demikian. Pak Sadi mengatakan `wah Pak Yun itu pamong
Mbak, putranipun Pak Lurah Almarhum ' (Wah Pak Yun itu pamong desa, anak almarhum Pak Lurah). Status sosial dalam berbagai kesempatan mengalahkan faktor lain seperti faktor usia. Dalam masyarakat Jawa jabatan kemasyarakatan dinilai sebagai sebuah kehormatan, hal ini dilihat dari fungsi dan kewenangan seseorang melalui jabatan yang disandang (Ismawati Esti, 2005).

Birokrasi dalam KT Sumber Rejeki menentukan bagaiamana arah komunikasi berlangsung. Birokrasi kelompok melalui struktur kepengurusan memunculkan adanya komunikasi vertikal dan komunikasi yang bersifat horizontal. Komunikasi vertikal terjadi antar bagian dalam kelompok yang dihubungkan melalui garis kepengurusan. Sebagai contoh adalah komunikasi yang terjadi antara ketua kelompok dengan bendahara atau sekretaris. Dalam sistem organisasi komunikasi ini disebut dengan topdown communication.

Komunikasi verikal ini terjadi hanya dalam beberapa isu seperti penugasan, pemberian perintah kerja atau pemberian informasi. Sebagai contoh adalah ketua Bapak Karjiyo memberikan perintah kepada Bapak Haryanto (sie humas) untuk mengikuti pelatihan yang diadakan oleh dinas pertanian Provinsi DI Yogyakarta. Perintah ini diberikan oleh ketua kepada anggota kelompok sebagai perintah kerja. Dengan mengikuti pelatihan yang dimaksud maka setelah pelatihan maka aka nada laporan kepada ketua selaku pemberi perintah. Ketua akan mensosialisasikan hasil pelatihan pada rapat rutin kelompok. 
Komunikasi yang bersifat horizontal adalah komunikasi yang berlangsung antar individu dalam kelompok yang memiliki level yang sama dalam struktur kepengurusan. Sebagai contoh adalah komunikasi yang terjalin antar sie perlengkapan Bapak Tukiman dan Bapak Nursahid. Keduanya adalah partner sebagai sie perlengkapan, jika ada kegiatan yang memerlukan perlengkapan khusus maka keduanya harus berkoordinasi dan berkomunikasi sebagai bagian dari penugasan kelompok.

Komunikasi dalam KT Sumber Rejeki memiliki maksud untuk mencapai tujuan kelompok. Peneliti selama observasi mengkaji terntang pemanfaatan media yang digunakan untuk berkomunikasi. Selain komunikasi verbal dan nonverbal komunikasi dalam KT Sumber Rejeki juga menggunakan media seperti surat menyurat maupun pemanfaatan alatalat komunikasi seperti handphone, internet dan speaker sebagai sarana pengumuman.

Surat menyurat dilakukan untuk memberikan penugasan, memberikan pengumuman (undangan pertemuan) dan digunakan sebagai arsip kelompok. Surat menyurat juga merupakan media utama dalam komunikasi eksternal. Dalam berbagai kegiatan permohonan proposal kegiatan kelompok melalui ketua mengirimkan surat dan proposal kepada lembaga terkait. Jawaban yang didapatkan juga melalui surat menyurat dan selanjutnya ditindaklanjuti dengan komunikasi bentuk lainnya.

Kelompok melalui birokrasi memiliki fungsi pokok yaitu fungsi regulasi, integrasi dan persuasi.
Komunikasi dinilai dapat menjembatani dalam mewujudkan fungsi terbebut. Kelompok melalui seperangkat aturan yang disepakati meregulasi seluruh kegiatan dalam kelompok. Tanpa berkomunikasi regulasi hanyalah sebuah aturan, sosialisasi dan pelaksanaan dari regulasi membutuhkan komunikasi sebagai sarana terciptanya kelompok yang teregulasi dengan baik.

Fungsi komunikasi sebagai integrasi dalam kelompok nyata terlihat melalui fungsi komunikasi dalam penyebaran informasi. Keberhasilan komunikasi dapat meningkatkan integrasi dan rasa kesatuan yang ada dalam kelompok. Informasi terkait kegiatan yang dilakukan dapat menambah kekompakan anggota jika informasi dapat diterima oleh semua anggota.

Komunikasi dalam organisasi
dapat digunakan untuk melakukan
persuasi melalui negosiasi dan lobby. Hal ini dapat dilihat melalui upaya pengurus untuk melakukan persuasi dalam pengajuan proposal kegiatan kepada pihak eksternal (komunikasi eksternal). Dalam komunikasi internal pengurus melakukan komunikasi persuasi melalui sosialisasi terkait manfaat adanya kegiatan dengan tujuan dapat mempersuasi anggota untuk turut serta dalam kegiatan yang dilakukan. Fungsi komunikasi sebagai integrasi, regulasi dan persuasi sangat terlihat dalam KT Sumber Rejeki. Hal ini menekankan bahwa komunikasi adalah faktor yang penting untuk menunjang keberlangsungan organisasi dan upaya pencapaian tujuan kelompok.

Budaya organisasi dapat disimpulkan sebagai aturan dalam 
berperilaku dalam KT Sumber Rejeki. Nilai yang ada dalam budaya organisasi menjadi pedoman dalam berperilaku termauk berkomunikasi. Nilai dalam budaya organisasi akan memberikan label terkait tindakan baik dan buruk, boleh dilakukan dan tidak boleh dilakukan. Nilai- dasar organisasi dalam KT Sumber Rejeki adalah nilai- nilai yang disepakati baik secara tertulis maupun secara kultural.

Elemen budaya organisasi dapat dikaji sebagai elemen idealistik dan elemen behavioural. Secara keseluruhan elemen idealistik anggota KT Sumber Rejeki adalah idealisme sebagai orang Jawa yang memiliki rasa toleransi, tenggang rasa, saling menghormati dan sopan santun. Elemen ini mengakar dari sistem budaya Jawa dimana kelompok ini terbentuk. Sedangkan elemen behavioural lebih dapat dikaji secara nyata melalui perilaku anggota kelompok. Labelisasi memberikan batas terkait elemen behavioural. Anggota kelompok akan menjaga perilakunya sedemikian rupa agar tidak menyalahi aturan secara kelompok dan aturan social secara khusus. Kecenderungan muncul perilaku yang dinilai baik dan menghindari perilaku- perilaku yang dinilai negatif. Dalam berbagai kesempatan budaya organisasi dibentuk sedemikian rupa unuk menjadikan organisasi ini lebih baik, namun tidak semudah yang dibayangkan, norma sosial dan kaitan budaya Jawa lebih mendominasi sebagai nilai yang dianut oleh anggota kelompok.

\section{KESIMPULAN}

Perilaku komunikasi internal berbeda dengan perilaku komunikasi eksternal. Perilaku komunikasi internal bersifat informal terdapat penggunaan bahasa yang disesuaikan dengan kaidah norma dan peraturan yang berlaku. Relasi internal menunjukkan bahwa struktur jabatan dalam kelompok menentukan pola komunikasi. Senioritas secara umur, tingkatan ekonomi serta jabatan sosial kemasyarakatan menjadi faktor penentu pembentukan perilaku komunikasi. Komunikasi internal lebih ekspresif, santai dan mengaburkan batas- batas yang tidak nampak dalam komunikasi eksternal.

$$
\text { Birokrasi dalam kelompok }
$$
membuat aliran informasi mengikuti pola struktur yang dibentuk. Ketua dan pengurus menjadi agen informasi karena mereka yang memiliki kewenangan berkomunikasi dengan pihak eksternal. Komunikasi yang sangat terlihat bersifat top-down adalah komunikasi dengan tema pekerjaan serta penugasan. Birokrasi kelompok bersifat terbuka, hal ini ditunjukkan dengan keluwesan serta sifat kekeluargaan yang senantiasa menjadi ciri khas komunikasi masyarakat Jawa.

Perilaku eksternal memperlihatkan perilaku komunikasi yang lebih dinamis. Anggota kelompok bersifat hati- hati dan menjaga hubungan dengan pihak eksternal dengan menunjukkan sikap menghormati ketika berbicara. Sifat yang ditunjukkan juga tidak seterbuka pada komunikasi internal. Perilaku yang ditunjukkan lebih bersifat halus, santun dan teratur melalui penggunaan bahasa dan perilaku nonverbal sesuai dengan norma yang berlaku dikebudayaan Jawa. 
Secara keseluruhan perilaku yang ditunjukkan merupakan perilaku komunikasi yang akomodatif. Perbedaan pendapat dan pandangan tidak ditonjolkan dalam pembicaraan. Divergensi tidak tampak secara riil, hanya dalam beberapa momen terjadi silang pendapat namun hal tersebut bukan merupakan isu yang krusial terkait kepentingan kelompok. Perilaku overakomodatif tampak dalam beberapa even ketika berbicara dengan pihak eksternal terutama pada seseorang yang dinilai penting seperti pemateri, petugas dinas pertanian maupun pejabat pemerintahan.

Budaya kolektif sangat tampak dalam upaya pengambilan keputusan secara musyawarah mufakat. Perilaku yang ditunjukkan bersifat homogen. Hanya satu atau dua individu yang memiliki perilaku yang secara karakter dasar berbeda dengan mayoritas. Beberapa individu terlihat memiliki power distance dengan anggota lain, hal ini berkorelasi dengan jabatan dalam kelompok maupun jabatan sosial diluar kelompok.

Setiap perilaku anggota kelompok tidak dapat dipisahkan dengan norma sosial serta aturan yang disepakati dalam kelompok. Hal ini terlihat dari upaya yang dilakukan anggota untuk senantiasa menjaga perilaku dalam berkomunikasi. Penelitian ini menunjukkan bahwa budaya organisasi melalui seperangkat aturan menjadi rujukan dalam menentukan perilaku komunikasi anggota kelompok.

\section{DAFTAR PUSTAKA}

Arifin, Anwar. 1984. Strategi Komunikasi: Suatu Pengantar Ringkas. Bandung: Armico

Denzin, K Norman. 1997. Handbooks of Qualitative Reseach.

California,USA: Sage Publication

Devito, A Joseph. 1986. The Interpersonal Communication Book. New York : Harper \& Row Publisher

Goldberg, A Alvin \&Larson, E Carl. 2006. Komunikasi Kelompok. Jakarta: Penerbit Universitas Indonesia

Gudykunst, B William \& Mody Bella. 2002. Handbook of International and Intercultural Communication. California: Sage Publication

Ife Jim \& Tesoriero Frank. 2006. Community Development. Yogyakarta: Pustaka Pelajar

Jensen B Klaus \& Jankowski, W Nicholas. 1992. A Handbook of Qualitative Methodologies for Mass Communication Research. New York: Routledge

Muhammad Arnis. 2002. Komunikasi Organisasi. Jakarta: Bumi Aksara

Soekanto, Soejarwo. 1986. Pengantar Sosiologi Kelompok. Bandung: Remaja Karya

Spadley, James. 1997. The Ethnographic Interview, California: Wadsworth Publishing

Tannen, Deborah. 1990. You just don't understand. New York: Ballantine.

Tubbs Stewart \& Moss Sylvia. 1996. Human Communication. Bandung: Rosdakarya

Turner, West. 2010. Introduction Communication Theory Fourth Edition. New York: Mc Graw Hill 


\section{UCAPAN TERIMA KASIH}

Redaksi Jurnal Humanika mengucapkan terima kasih atas partisipasi dan kesediaan Mitra Bestari untuk Volume. 15. Nomor. 1. September 2015, kepada;

Ajat Sudrajat (Universitas Negeri Yogyakarta) untuk artikel

1. "Islam Rahmah dan Wasathiyah (Paradigma Keberislaman Inklusif, Toleran dan Damai)" (Abd. Malik Usman)

2. "Etika Sosial dalam Kerukunan Umat Beragama (Studi Kasus di Desa Kotesan Kecamatan Prambanan Kabupaten Klaten Jawa Tengah)” (Andy Dermawan dan Zunly Nadia)

3. "Mencari Model Pendidikan Karakter" (Suparlan)

Suranto Aw (Universitas Negeri Yogyakarta) untuk artikel

1. "Persepsi Masyarakat Kotagede terhadap Pengunaan Media Komunikasi oleh Organisasi Forum Joglo untuk Pelestarian Budaya di Kotagede Yogyakarta” (Choirul Fajri)

2. "Implikasi Budaya Organisasi terhadap Pola Perilaku Komunikasi Kelompok Tani Sumber Rejeki” (Mariana Ulfah dan Siti Chotijah)

3. "Model Komunikasi "Wom” sebagai Strategi Pemasaran Efektif” (Dani Fadillah)

Yayan Suryana (Universitas Islam Negeri Sunan Kalijaga Yogyakarta) untuk artikel

1. "The Dialectics of Javanese and Islamic Cultures: an Introduction to Kuntowijoyo’s Thought” (Pradana Boy ZTF) 